Sciences

Vol. 07, No. 02, pp.30-46, June 2014

\title{
BEHAVIOUR OF CALCARIOUS SOIL SUBJECTED TO OIL DERIVATIVES
}

\author{
Safa Hussain Abid Awn ${ }^{1}$, Waad Abdulsattar Zakaria ${ }^{2}$ \\ ${ }^{1}$ Lecturer, ${ }^{2}$ Assistant Professor, College of Engineering, Diyala University, Iraq \\ E-mail: waadzakariya@yahoo.com. \\ (Received: 17/5/2012; Accepted: 24/3/2013)
}

\begin{abstract}
Calcareous or salty soils are the soils which are containing highly dissolved sodium or calcium salts in natural conditions. The dissolution of salts increases with temperature, atmospheric pressure, in addition to the acidity of the dissolves solution. Calcareous soil is stiff and very hard if it is in a dry phase; it becomes collapsible and very week when wetted with water. It is very dangerous for structures when constructing on such soil especially when high stresses are applied on it. Oil tanks or pipes may damage from any reason, and the oil products may leak from these structures to the soil and infiltrate through soil skeleton and may cause leaching to $\mathrm{CaCO}_{3}$ salt particles in some regions in Iraq, as example the Baiji Oil Station or Al-Mosel Dam, $\mathrm{CaCO}_{3}$ percent reaches more than $40 \%$.

This study shines the lights about the behavior of Calcareous soil subjected to three oil derivatives (kerosene oil, crude oil, gas oil and a sample wetted with water to make good comparison , and study effect of addition of this products on the collapsibility.

A laboratory model included soil with $70 \%$ and $50 \% \mathrm{CaCO}_{3}$ compacted to $11 \mathrm{kN} / \mathrm{m}^{3}$. Fix stress system was used which applies $50 \mathrm{kN} / \mathrm{m}^{2}$, the loading frame was manufactured in a way that keeping the weights over footing stable without tilting. Three oil derivatives (Kerosene, Gasoil and crude oil) were used for laboratory model tests; by wetting Calcareous soil with it. One sample was wetted with water for comparison; the settlement was recorded with soaking time at a constant stress level.

The results of laboratory model tests shows that the settlements results from specimens soaked with lubricating oil, Gasoil and Kerosene, are much less than the settlements that belong to soaking with water (reduce settlement to about one third) and considered high improvement of such problematic soil by wetting with oil derivatives.
\end{abstract}

Keywords: Calcareous soil, behavior, oil derivatives.

\section{INTRODUCTION:}


It has been started during the last two decades, a number of published data been reported concerning the geotechnical properties of Calcareous soils. Most of these data were oriented towards the compressibility, collapsibility, permeability and shear strength of Calcareous soils ${ }^{(1)(2)}$.

The mechanical behavior of Calcareous soils depended mainly on $\mathrm{CaCO}_{3}$ content, size and distribution of this salt in soils, dissolution and transport of it in soils in addition to the texture of the soils. The behavior and characteristics of Calcareous soil are different from that of classical soil, where $\mathrm{CaCO}_{3}$ salt acts as a cementing agent to the soil particles and as filler of the voids of the soil. The presence of water destroy this cementation, dissolve the salt in the pores, and if the water Flows out the soil it alters these characteristics of the soil that loses some of its solidity. The determination of $\mathrm{CaCO}_{3}$ content (which is a percentage of dry soil weight) is a complicated problem. Many methods were founded to determine the $\mathrm{CaCO}_{3}$ content. In general all methods fall in three categories: The gravitation methods, which depend on the determination of the sulfate content of the soil mixture. The volumetric methods depend on direct titration with barium chloride. While the subsidiary methods depend on empirical relations between conductivity and collapsibility or the action exchange (2).

Calcareous soil is unsaturated soil that goes through a radical arrangement of particles, and great loss of volume upon wetting with or without additional loading ${ }^{(3)}$. Knight 1963 measured the collapsibility in a different way which is called single collapse test, in which a sample is fitted in the consolidometer ring and then the load is applied progressively until $200 \mathrm{kPa}$ is reached ${ }^{(4)}$. At the end of loading, the specimen is flooded with water and left for a day, the consolidation test is carried on to its maximum loading.

There is no unique definition for Calcareous soils used by civil engineers. It can be stated that a soils is a Calcareous soil when it has gypsum content enough to change, or to effect on its engineering properties ${ }^{(5)}$.

Calcareous soil is a very hard material when it is in dry state. Upon wetting the binders between particles will be broken, that will cause softening of the soil under the footing and sudden collapse of structure will occur ${ }^{(6)}$. Calcareous soils are often used as the natural foundation bases for loading and structure. The presence of $\mathrm{CaCO}_{3}$ in these soil represent one of most complex engineering problem due to its detrimental behavior, especially when accompanied by environmental change in moisture content, temperature and presence of certain types of salts ${ }^{(7)}$.

Civil engineers face severe problems when constructing on and in Calcareous soils, e.g. corrosive effect of sulphate concrete, the free $\mathrm{CaO}$ in concrete react with sulphate dissolved in irrigation water or seeping water under formation of ettringite (Calcium 
Aluminum sulphate). Ettringite contains 31 molecules of crystal water and the presence of this materials leads to swelling and slow disintegration of the concrete. This problem overcomes by using sulphate-resistant comet ${ }^{(8)}$. The failure by excessive leakage may take place because of defect in structural arrangement of the underlying street if they contain collapsible materials. ${ }^{(9)(10)}$.

One of Chemical treatment of some calcareous soils is presented by the addition of $4 \%$ clinker to it. This will decrease settlement more than $73 \%{ }^{(11)}$.

\section{EXPERIMENTAL WORK}

\section{Soil Used:}

The soil used in this study was brought from Bakuba discrete at $1.25 \mathrm{~m}$ depth of handmade borehole. The decision was made for taking this region after several isitue tests by "Bottle Quick test", which carried out to fined the ingredients of soil in an approximate order. The sedimentation took place for few hours. Most of soil used in this study was fine grained soil. In this quick test, two kilograms of natural soil is placed in a deep jar, or a bottle ${ }^{(14)}$, shaking the soil with water to make a uniform suspension. According to Stokes law of sedimentation, first of all, sand settles down first within one and half minutes, silt may take five minutes, clay takes several hours to settle down.

The relative quantities of materials can be obtained by observing the depth of several materials in the bottom sediment of jar or bottle. The test shows large amount of silt and clay. Grain size analysis is conducted on two specimens, one using the natural soil classified as "ML", and the other using a soil mixture of natural soil with sandy soil brought for test in a mix proportion of one to one, which prepared to use for laboratory model tests. This soil is artificially prepared and mixed thoroughly with different $\mathrm{CaCO}_{3}$ content: $50 \%$ and $70 \%$. A single proctor compaction test is later carried out on the soil that is to get the maximum dry density with the optimum moisture content, i.e. the $\mathrm{MDD}=19.6 \mathrm{kN} / \mathrm{m} 3$ and $\mathrm{OMC}=8.3 \%$. Again the soil used for the compaction consists of one part of mixed soil (that is natural soil with sandy soil in $50 \%$ to $50 \%$ proportions) and one part of $\mathrm{CaCO}_{3}$. This test was conducted in order to estimate how much density is to be used in the tests. It is feared that a very compacted Calcareous soil may not reflect well the problem of collapsibility and the problem of behavior and improvement. Here trial tests are inevitable and have to be done in order to see how much density is to be used in models. The testing program for this study are shown in figure (1).

\section{Model Preparation and Testing Methodology:}


Technically, two identical hard plastic containers, each of diameter of $0.35 \mathrm{~m}$ and depth of $0.4 \mathrm{~m}$, are used to compact Calcareous soil to a dry unit weight of $11 \mathrm{kN} / \mathrm{m}^{3}$ with molding water content of $3.2 \%$. A layer of dry sand of dry sand is played down at bottom of container. This layer is considered essential for the drainage of the Calcareous soil during leaching. Drain holes are made through the bottom of the container. So no water is perched into the container. The Calcareous soil is prepared outside the container and mixed thoroughly with $3.2 \%$ of water. The mixture is poured into the container in three layers, each $6.35 \mathrm{~cm}$ and compacted using the standard proctor tamper. Eventually the thickness of Calcareous soil is about $20 \mathrm{~cm}$.

The plastic container with the Calcareous soil prepared into it is placed near a large steel table. The steel loading frame is fixed to the steel table and the dial gauge is attached to the table as well.

A small steel plate having dimensions $3.2 * 4.5 \mathrm{~cm}$ is placed on the surface of the Calcareous soil. This plate represents the footing. The loading frame is placed on the steel footing with weights attached on it as to support a pressure on soil of $55 \mathrm{kPa}$. This pressure is chosen as it is believed that most domestic hours and small engineering facilities may apply a similar pressure on soil. The dial gauge is leveled to an initial reading representing the zero point, and readings for settlement are begun to be recorded. The reading process is terminated when the settlement of the footing is approximately ceased, as shown in figure (2).

Three types of oil derivatives (Gasoline, Kerosene, Crude oil, in addition to water) are added carefully to the container, and the period of soaking and leaching is begun. Settlement readings are recorded for approximately 1 week. The steps mentioned are repeated for all models to study the behavior of Calcareous soil subjected to these liquids.

\section{RESULTS AND DISCUSSION:}

As mentioned earlier in sample preparation that two soil specimens are used. One is mixed with 50 percent by weight of $\mathrm{CaCO}_{3}$, the other mixed with 70 percent of $\mathrm{CaCO}_{3}$. Before that, the soil itself consists of $50 \%$ by weight of sand mixed $50 \%$ of soil brought from a nearby location, about $100 \mathrm{~m}$ behind the civil engineering building. That is done since the pure natural soil obtained contains high amount of fine grained soil. It is feared that the permeability will became too low thus requiring much time for soaking periods. The two percentages of $\mathrm{CaCO}_{3}$ salt are so chosen to reflect the sever conditions of soil that are indeed available and do exist in Iraq, namely in the middle north region. Figure (3) to (9) show the time-settlement relations for all Calcareous soil models contain different $\mathrm{CaCO}_{3}$ content, and wetted with different oil derivatives, to show the effect of these liquids on the collapsibility of 
such problematic soil tested at (stress level $=50 \mathrm{kPa}$, soil dry unit weight $=11 \mathrm{kN} / \mathrm{m}^{3}$. Fig (10) shows all curves for data accumulation for soil under same loading condition but with different soaking liquid, i.e., water, gasoil, kerosene and crude oil. Here, fuels of gasoil and kerosene are chosen since they are rather safer to deal and handle with, also more safe than other fuels used for cars or aircrafts. It is intended to reflect the behavior of Calcareous soil when they are in touch with these types of oil derivatives, and hopping to draw useful conclusions out of this research that may help the domestic economy. This condition may rise when there is some leakage of oil derivatives in oil refinery or facility complexes, or in supplying stations of these types of oil derivatives to soil (or more precisely foundation soil) and for any technical or human purposes. And if foundation soil contains not of little amount of $\mathrm{CaCO}_{3}$ in its contents or ingredients, then the problem of collapse may be motivated at once or after some time.

Fig (10) shows, the curves which belong to oil derivatives soaking are to be compared with the one of water soaking only. And as we know that water triggers the collapse potential in Calcareous soils, the latter is to be treated as a reference guide to see which is more dangerous than water. The settlement is recorded with time, and the zero settlement is not when stress is applied to soil (through a $45^{*} 35 \mathrm{~mm}$ footing), rather the zero time and zero settlement are when soaking commences. So there is a portion (part) of settlement missing which belongs to the model footing when it is put onto soil. It must be mentioned here that this type of settlement is not included in study since the aim of research is to observe the settlement due to soaking only. Thus the mentioned settlement is not recorded. It is quite clearly that the settlement obtained when footing is flooded with water, for all models. Until time is about 100 minutes of starting time, all curves have quite similar trend and do go approximately parallel. Then after that the other two curves level off except the water curve which continue to settle down without stopping but not until two days, the settlement-time curve levels off and last two recorded settlement readings are approximately equal, and thus it can be said that finally settlement stops, having $S / B=8.11 / 45=0.18$ which is very high ratio. To imagine how much is large, we consider a domestic house foundation of $1.2 \mathrm{~m}$ width. The measured settlement, in a similar way, would give a collapse settlement of $220 \mathrm{~mm}$ which is far behind any domestic structure to withstand, thus reflecting the critical situation of footing erected on Calcareous soils. And as listed in so many research works, building directly over Calcareous soils without any counter measurements taken is a very bad economic policy.

On the other hand, the Gasoline curve settles down in a rather uniform rate to level off finally at a settlement rate of $\mathrm{S} / \mathrm{B}=2.03 / 45=0.05$. In the case of domestic house, we will get a settlement of $60 \mathrm{~mm}$ for building footing which is highly but not as the curve of wetting with water. This certainly reflects a fact that the soaking with gasoil is less critical than water. So 
one should be concerned with water reaching Calcareous soil beneath foundation more than gasoil problem, but we cannot say that soaking with it not a critical case.

The Kerosene curve is quite similar to the gasoil curve except in the last recorded points, the Kerosene shows little higher settlement than the gasoil curve. The measured S/B for the kerosene curve is $2.55 / 45=0.06$ which is little higher than 0.05 . It is the other opinion that no sharp conclusion can be drawn on which S/B ratio is higher for the cases of Kerosene and gasoil since the two measured settlement differ in only $0.5 \mathrm{~mm}$. Nevertheless, we can conclude that both oil derivatives show much less collapsibility than the case of water, e.i. a factor of 3 folds in this study. It must mention that these types of settlements are almost considered as instantaneous, so it cause more distress to structures than the consolidation settlements even if they were of same magnitude since consolidation settlement occurs gradually through many years, at that interval of time, the building structure redistribute or readjust the resulting stresses unlike the collapse settlement which leaves no time for building to do so. Another note concerning the collapsible soils is that water triggers the potential of collapsibility as well as other liquids as this study confirms. Authors believe that the policy of preventing water to be in touch with such soils is a false policy. They feel it is rather impossible to do so, thus resorting to other types of solution which must be practical is the best policy.

Fig (11) shows the curves for data accumulation of soil specimens soaked with same liquids as for Fig (10) in addition to soaking one soil specimen in ordinary lubricating oil. This mixture is prepared as $70 \%$ by weight of $\mathrm{CaCO}_{3}$ with $30 \%$ by weight of soil. The soil without $\mathrm{CaCO}_{3}$ is prepared, as mentioned earlier, by mixing $50 \%$ of sand with $50 \%$ of natural soil brought from a nearby place behind the civil engineering building, as to accelerate time required for each test specimen, since only one loading device is available). The curves in Fig (9) represent sever condition of soil that contain very high amount of $\mathrm{CaCO}_{3}$ content. So these curves may give good and close to reality condition for severity of collapse potential of Calcareous soils. The loading condition and testing are the same for all specimens and similar as well for the specimens shown in Fig (10) earlier.

First of all we start, as we did before in Fig (10), with the reference specimen, that is the one treated with water only since it will be the base of comparison among others, initially. Speaking us say that all curves show similar trend as compared with Fig (10) but with rather larger recorded settlements. The settlement for soil specimen soaked with water continued to take place until 6 days (8580 minutes), and stopped later, i.e., drawn curve leveled off. The final settlement recorded is $13.14 \mathrm{~mm}$. This value represents on $\mathrm{S} / \mathrm{B}$ ratio of $13.14 / 45=0.3$, which is a very high ratio. And to imagine again this number we return to our domestic house foundation which is $4 \mathrm{ft}$ of width or $1.2 \mathrm{~m}$. So in this case we may get a collapse 
settlement of $0.3^{*} 1200 \mathrm{~mm}=360 \mathrm{~mm}$ or 14.2 inches. This is extremely high collapse settlement that major types of buildings cannot withstand. Authors believe that this high instantaneous settlement may not only causing cracks in the building but may damage structural elements (slabs, beams and connection points) due to high collapse of footings constructed on such problematic soil. This fact is kept in mind because this type of settlement is potential collapse settlement as it occurs almost in instantaneously in soil mechanics terminology. So all possible methods and means must be taken in to account, to reduce this potential collapse and also to take special structural measures in the building design as well for such high amount of settlement.

On the other hand, the final settlement recorded for cases of soil specimens soaked with gasoil and lubricating oil are quit close that is $3.82 \mathrm{~mm}$ and $3.6 \mathrm{~mm}$ respectively. In other words an S/B ratio of 0.085 and 0.080 or simply say 0.085 for both. The settlement ratio is also high and gives a settlement of potential collapse of $0.085^{*} 1200 \mathrm{~mm}=102 \mathrm{~mm}$ for the ordinary domestic house having $1200 \mathrm{~mm}$ width, footing. 10 centimeters of settlement is very high to be acceptable for any structures, but yet it is much less than one third of the settlement measured for specimen soaked by water i.e. $360 \mathrm{~mm}$. There is major difference between the settlement-time curves for specimens soaked with gasoil and lubricating oil, that is the oil-curve quickly drops down at time 35 minutes ad approximately leveled-off to late time intervals while the gasoil-curve takes a gradual rate of drop down. And since the settlement is faster reached in the oil-curve case, it is concluded that the oil is more critical to Calcareous soil than the gasoil, although both curves levels off to approximately same S/B ratio. This is so since the faster rate of settlement is more troublesome and show greater distress to building than the slow rate of settlement, even if they are of same final magnitude.

Meanwhile, the specimen soaked with Kerosene shows both faster rate and higher magnitude of settlement than both the lubricating oil and the gasoil cases. It is worth to mention that the situation of $50 \%$ of $\mathrm{CaCO}_{3}$ content specimen show similar trend but less magnitude and rate in case of Kerosene specimen. The final S/B ratio for the Kerosene specimen is $5.9 / 45=0.13$, which is very high in terms of total settlement for structures or domestic buildings.

It must be mentioned here, that the recorded settlement belongs to soaking merely and do not conclude the settlements that represent leaching. Fig(12) shows a bar chart for the final settlement recorded at the end of soaking test of Calcareous soil models for the two soils with different $\mathrm{CaCO}_{3}$ content $50 \%$ and $70 \%$ tested at the same conditions and shows the effect of wetting such problematic soil with some oil derivatives. 


\section{CONCLUSIONS:}

From the recorded measurements of this experimental study, the following points are drawn:

1- The natural soil obtained from two nearby spots behind civil department, have very low permeability, that why 50 percent by weight of sand is mixed in order to accelerate the test of soil specimens.

2- The soil in step one is mixed with 50 and 70 percent by weight of $\mathrm{CaCO}_{3}$, that is to get artificially calcareous soil instead of natural one. This is so because it is rather difficult and expensive to look for two natural specimens of Calcareous soils having same soil composition but different $\mathrm{CaCO}_{3}$ contents. The results obtained from a Calcareous soil specimen is far away from reality, however, the Calcareous soil specimen reflects the realistic behavior of actual Calcareous soils. Nevertheless many early and late studies use artificially prepared soils instead of natural Calcareous soil for purpose, and others, listed before.

3- As expected increasing $\mathrm{CaCO}_{3}$ content increases the settlement recorded.

4- Soaking with water only provided an $\mathrm{S} / \mathrm{B}$ ratio of 0.18 and 0.29 for $\mathrm{CaCO}_{3}$ contents of $50 \%$ and $70 \%$ respectively. These ratios are considered very high to be withstand in any ordinary domestic buildings, putting in our terminology that these settlements occur almost suddenly (collapse settlement make the problem more worse), for instance consolidation settlements which occur during long durations time, in turn, giving building time readjusting itself or additional stresses coming from either differential or uniform settlement.

5- In general, settlements recorded for specimens soaked with lubricating oil, Gasoil and Kerosene, are much less than the settlements that belong to soaking with water (reduce settlement to about one third) and considered high improvement of such problematic soil by wetting with oil derivatives.

6- The settlement obtained from soaking Calcareous soil by Kerosene show high rate and magnitude than the oil and gasoil specimens.

7- It can be concluded that since the collapse settlement for Calcareous soils soaked with oil derivatives is less than that of water, designers should be concerned with water more than concerning to some oil derivatives.

\section{REFERENCES:}

1. Abed Awn, S. H. 2004,'”Improvement of collapsible soils using locally manufactured reinforcement materials" Ph.D. Theses, Building and Construction Department, University of Technology. 
2. FAO 1990, Management of collapsible Soil, Food and Agricultural Organization of the United Nation, Rome.

3. Clemence, P. S. and Finbarr, A. O. 1981," Design considerations for collapsing soils", Journal of the Geotechnical Engineering Division, ASCE, Vol. 107, No.GT3, pp.305317.

4. Knight K. 1963,"The origin and occurrence of collapsing soils, Proceeding of the $3^{\text {rd }}$ Regional Conference of Africa on Soil Mechanics and Foundation Engineering Vol. 1, pp.127-130.

5. Nashat, I. H. 1990, Engineering characteristics of some collapsible soils in Iraq, Ph.D. Thesis, Department of Civil Engineering, University of Baghdad.

6. Al Muhammadi N. 1987, "Compressibility and collapse of collapsible soils", proceeding of the $6^{\text {th }}$ Asia conference of soil mechanics, Tokyo.

7. Al Qaissy F. F. 1989," Effect of gypsum content and its migration on the compressibility and shear strength of gypseous soil, M. Sc. Thesis, Building and construction department, University of Technology.

8. Alphen, J. G. and Romro, F. R. 1971,'Gypseous soil, notes on their characteristics, and management, internatunal inistitute for land reclamation and improvement, Wageinge, Netherland.

9. Fattah M. Y., Al Shakarchi Y. J. and Al-Nuaimi H. N., "Long term deformation of some gypseous soils”, Engineering and Technology Journal. Vol. 12, 2008.

10. Sarsam S. I. and Ibrahim S. W., "Contribution of Liquid Asphalt in Shear Strength and Rebound Consolidation Behaviour of Collapsible Soil”, Engineering and Technology Journal, Vol. 26, No.4, 2008.

11. Al-Neami M. M. (2010), "Improvement of gypseous soil by Clinker additive", Eng. \& Tech. Journal, Vol. 28, No. 19. (المكتبه الافتر اضيه)

12. -Talal S and Abdullah Sabtan" Geotechnical and geochemical properties of AlNekhaila sabkha, south of Jeddah", Journal of King Abd Al-Aziz, Earth Sciences ISSN, 1999, Vol. 11, pp161-176. Publisher KAU-Scientific Publishing Center. المكتبه) الافنر اضيه)

13. Valenza, A. and Gillot, J. C. "Influence of groundwater on the degradation of irrigation soils in a semi-arid region, the inner delta of the Niger River, Mali." Hydrology Journal ISSN, 2000, Vol.8, pp417-429. (المكتبه الافتر اضيه ("ال)

14. Joseph E. Bowles, 1996" Foundation analysis and design”, McGraw-Hill International Editions, Fifth Edition. 


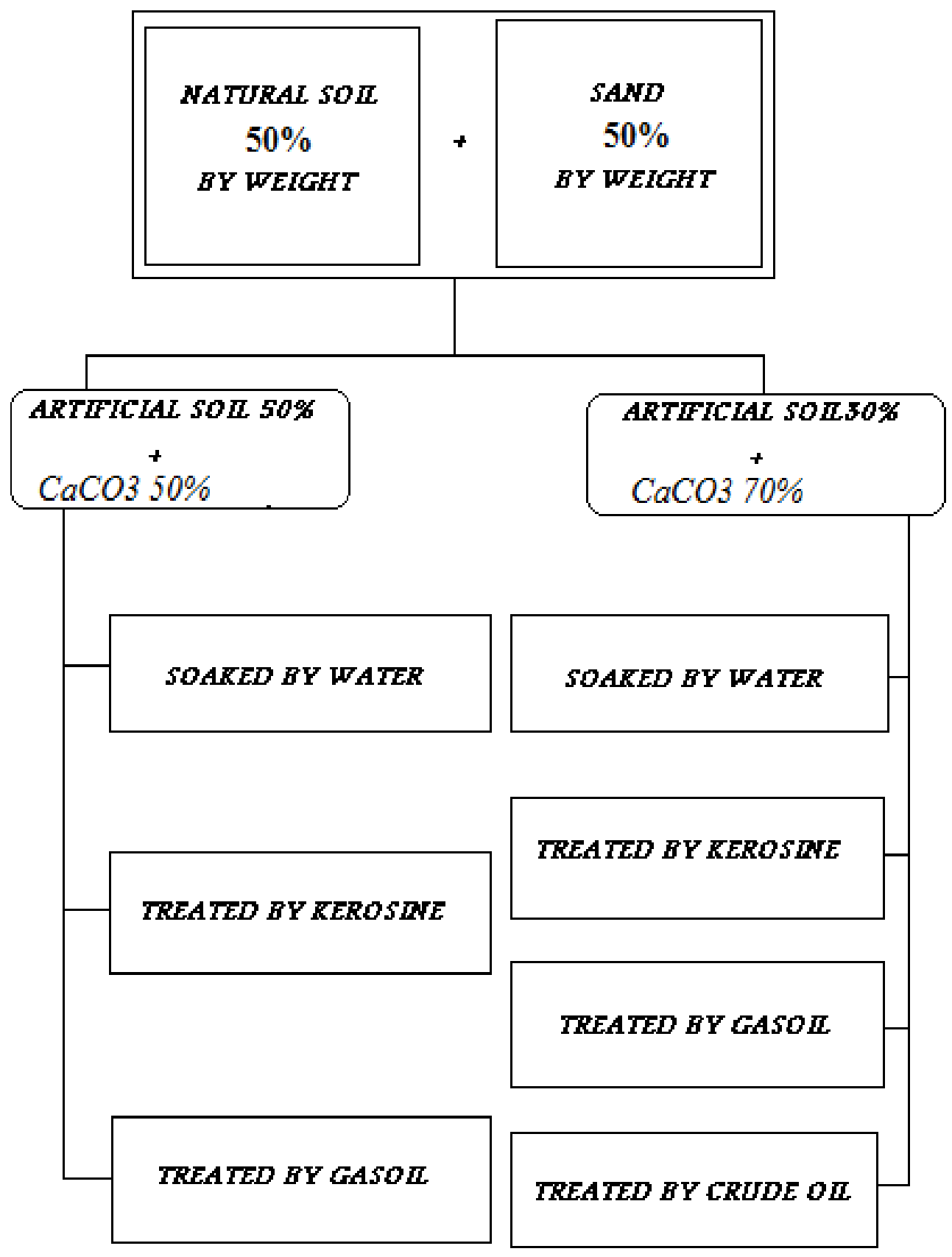

Fig. (1): Flowchart program of the Experimental work on the behavior of Calcareous soil subjected to some oil derivatives laboratory model tests. 

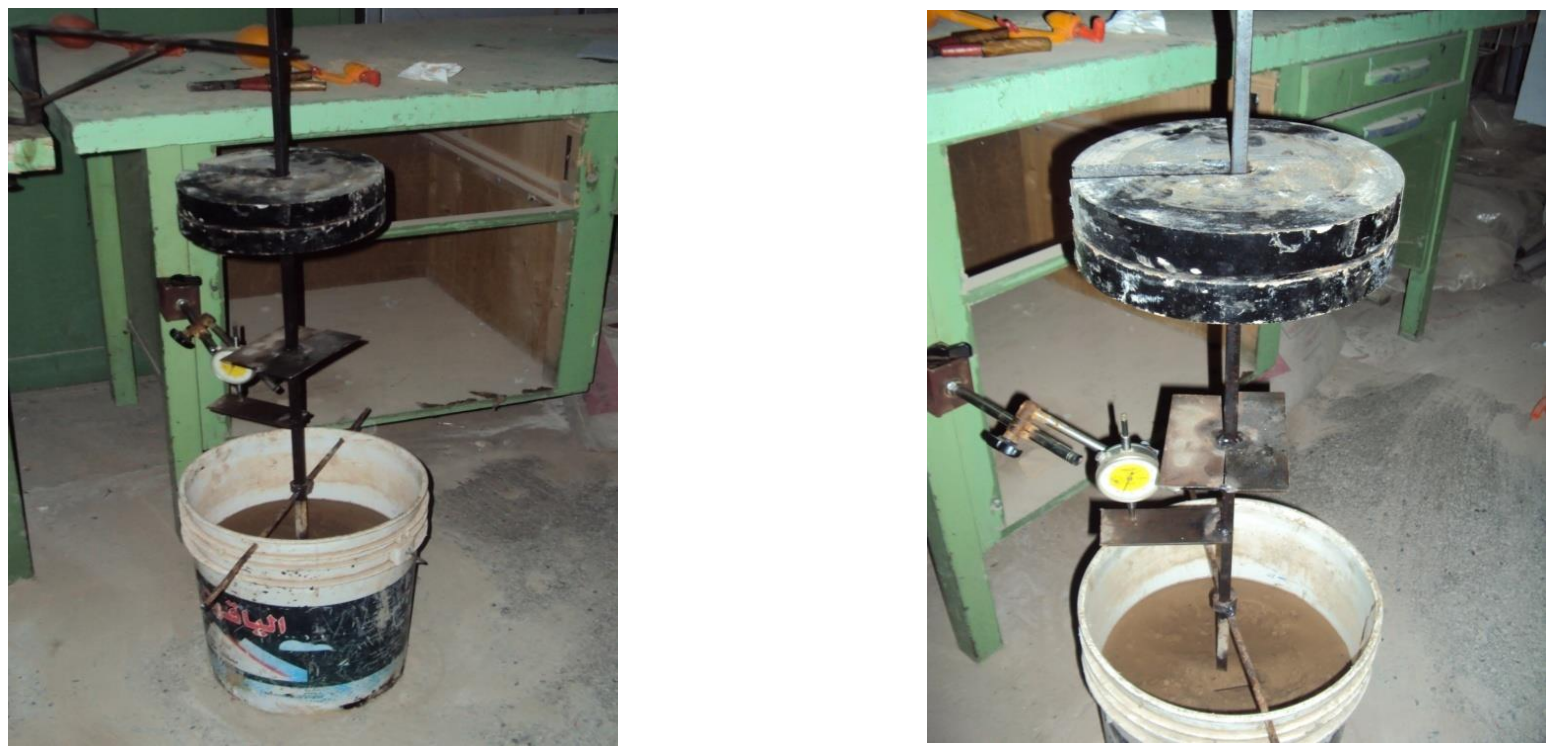

Fig (2): Laboratory model preparation and equipment's for soaking test by wetting Calcareous soil by some soil derivatives, loading system applying fix soaking stress (manufactured locally), soil placement and density control.

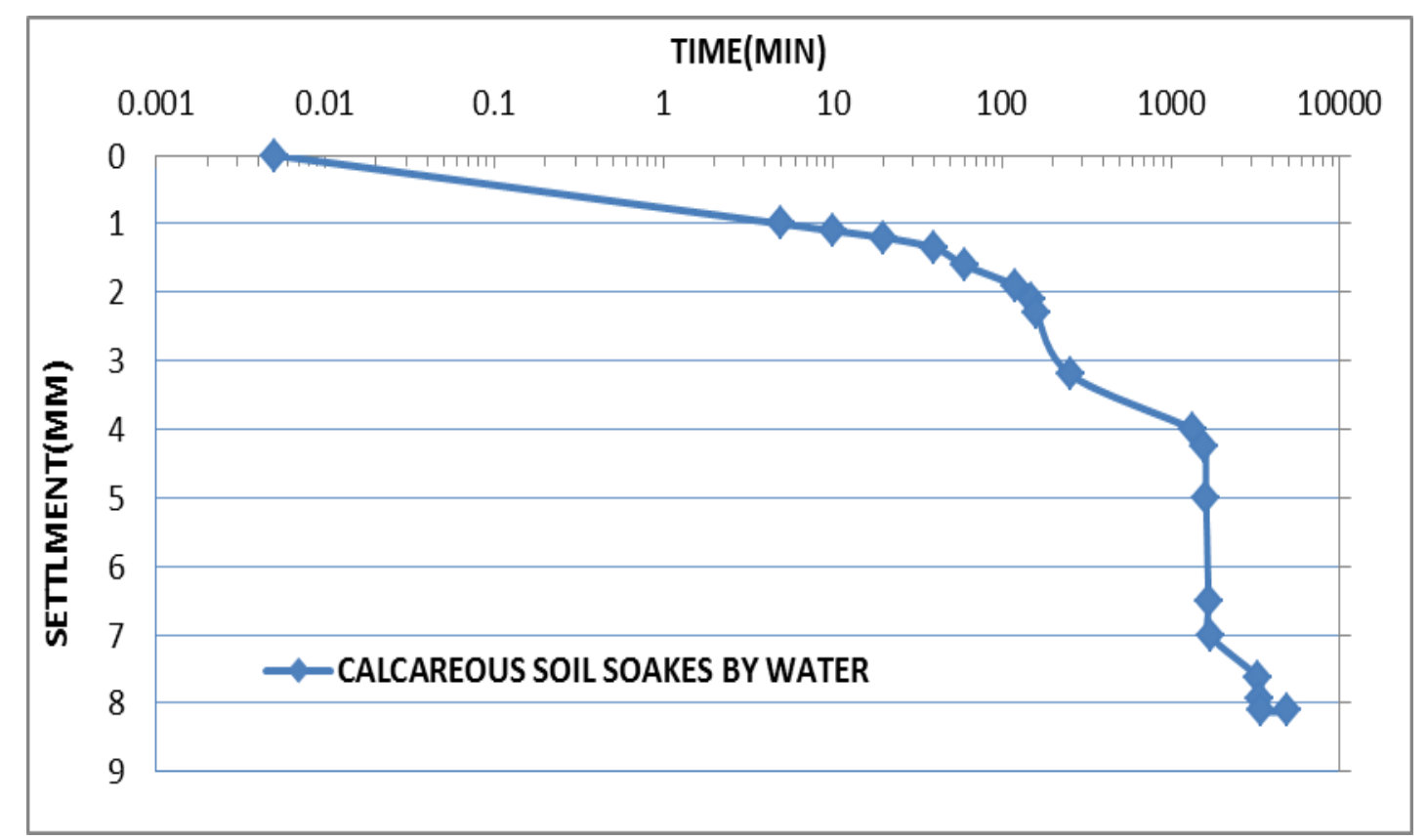

Fig. (3): Time-settlement curve for Calcareous soil laboratory model with $50 \% \mathrm{CaCO} 3$ content, soaked by water. ( soaking stress $=50 \mathrm{kPa}, \gamma \mathrm{d}=11 \mathrm{kN} / \mathrm{m}^{3}$ ). 


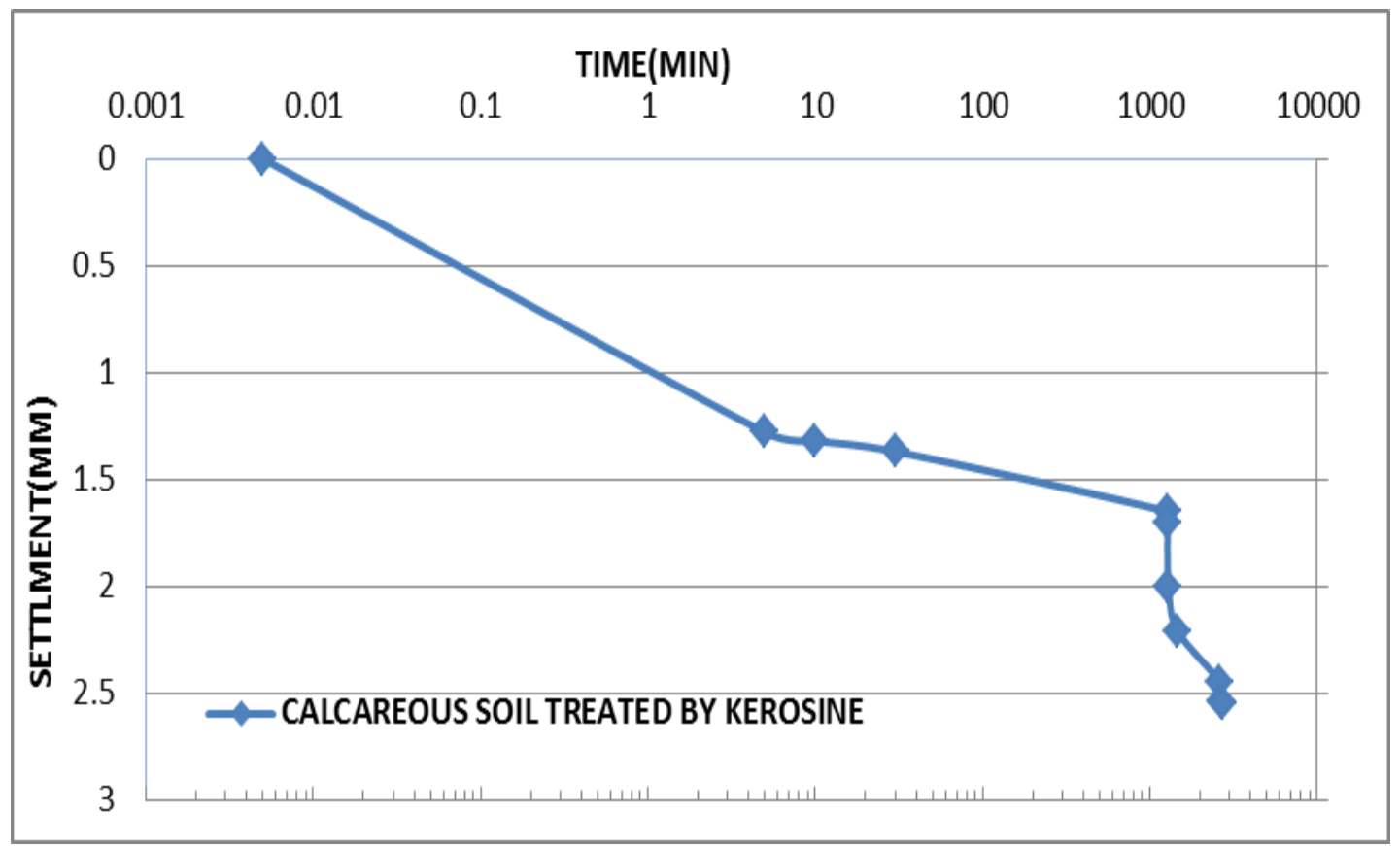

Fig. (4): Time-Settlement curve for Calcareous soil laboratory model with 50\% $\mathrm{CaCO}_{3}$ content, wetted by Kerosene. (soaking stress $=50 \mathrm{kPa}, \gamma \mathrm{d}=11 \mathrm{kN} / \mathrm{m}^{3}$ ).

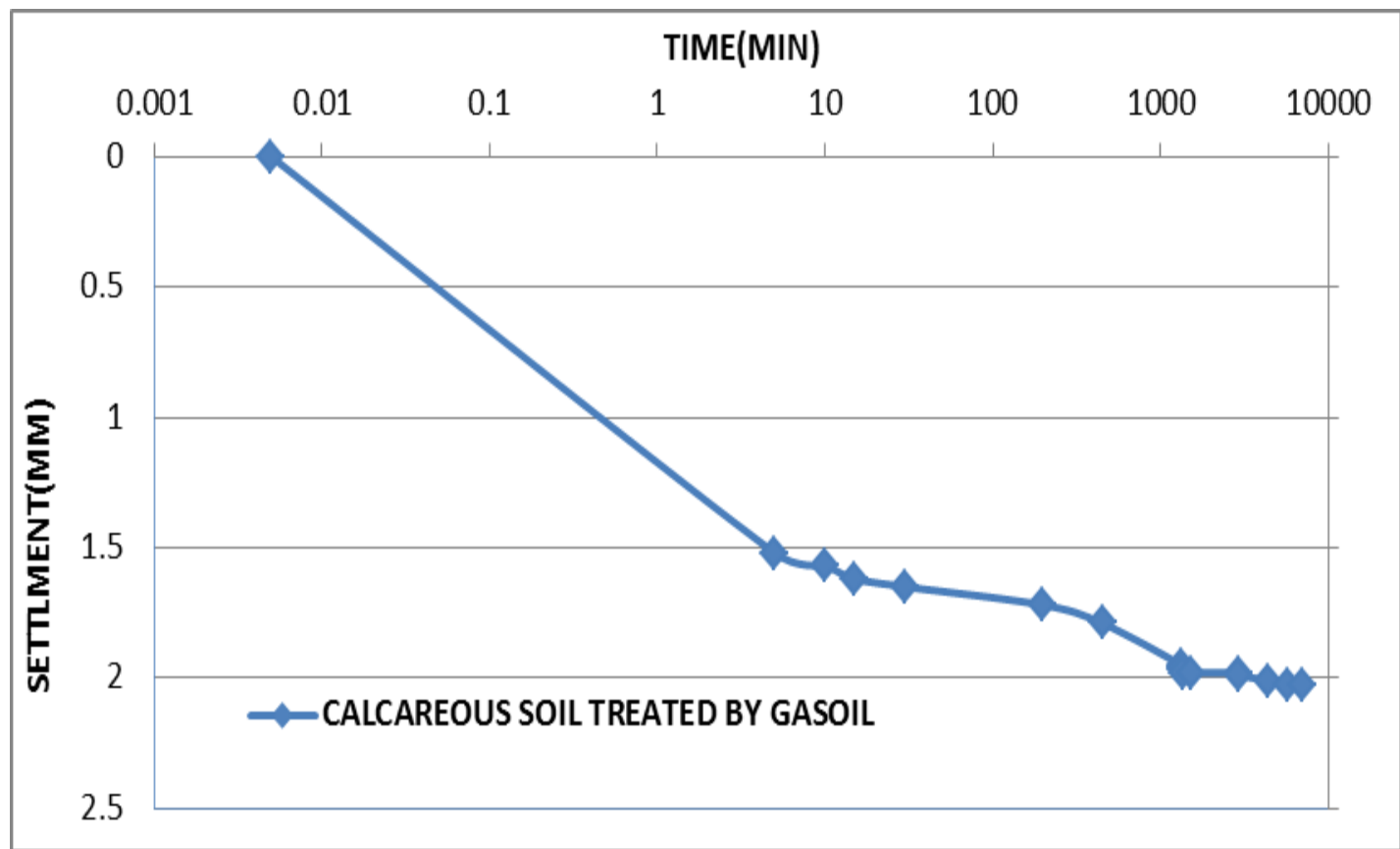

Fig. (5): Time-Settlement curve for Calcareous soil laboratory model with 50\% $\mathrm{CaCO}_{3}$ content, wetted by Gasoil. ( 


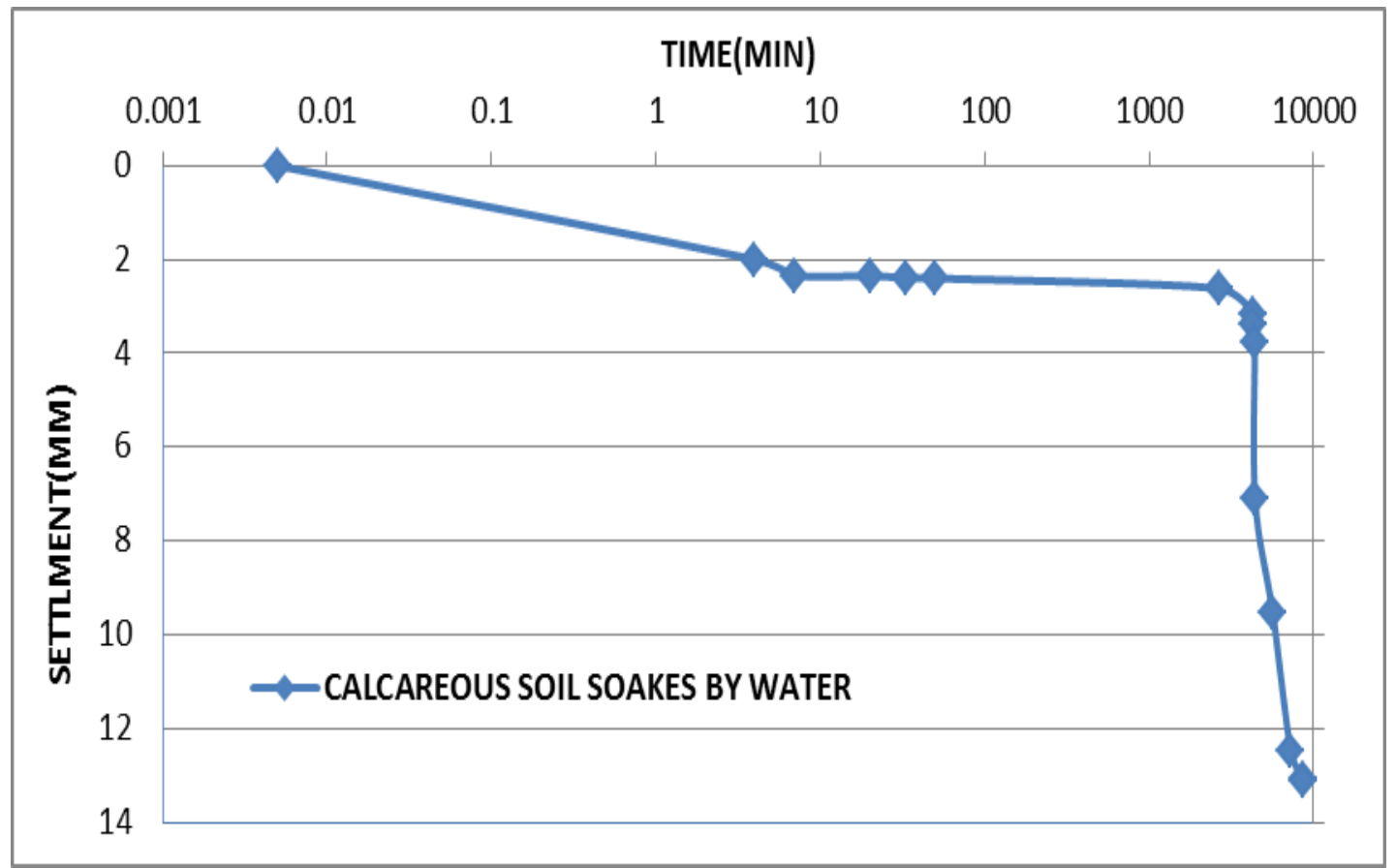

Fig. (6): Time-Settlement curve for Calcareous soil laboratory model with $70 \%$ $\mathrm{CaCO}_{3}$ content, soaked by water. (soaking stress $=50 \mathrm{kPa}, \gamma \mathrm{d}=11 \mathrm{kN} / \mathrm{m}^{3}$ ).

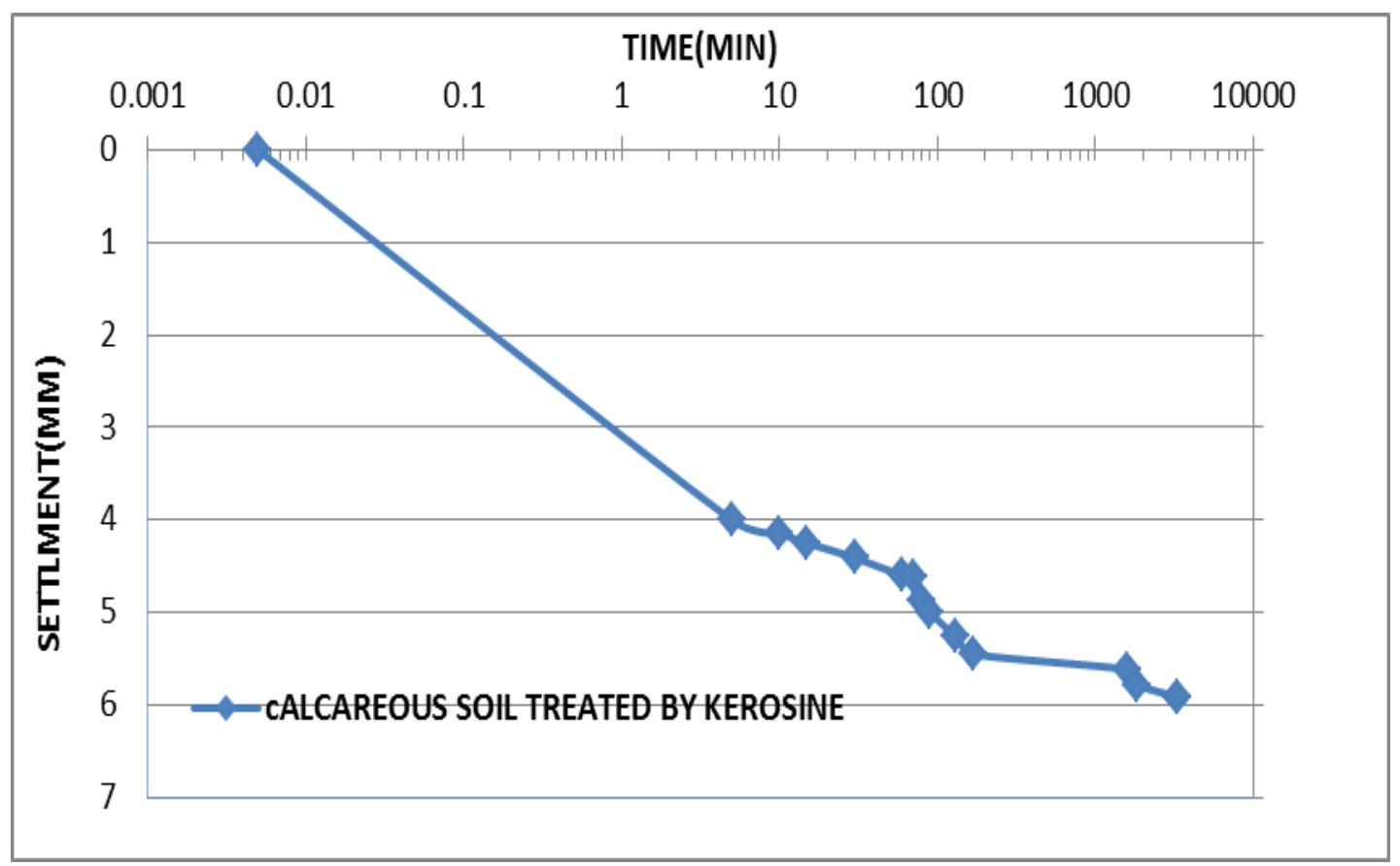

Fig. (7): Time-Settlement curve for Calcareous soil laboratory model with 70\% $\mathrm{CaCO}_{3}$ content, wetted by Kerosene. (soaking stress $=50 \mathrm{kPa}, \gamma \mathrm{d}=11 \mathrm{kN} / \mathrm{m}^{3}$ ). 


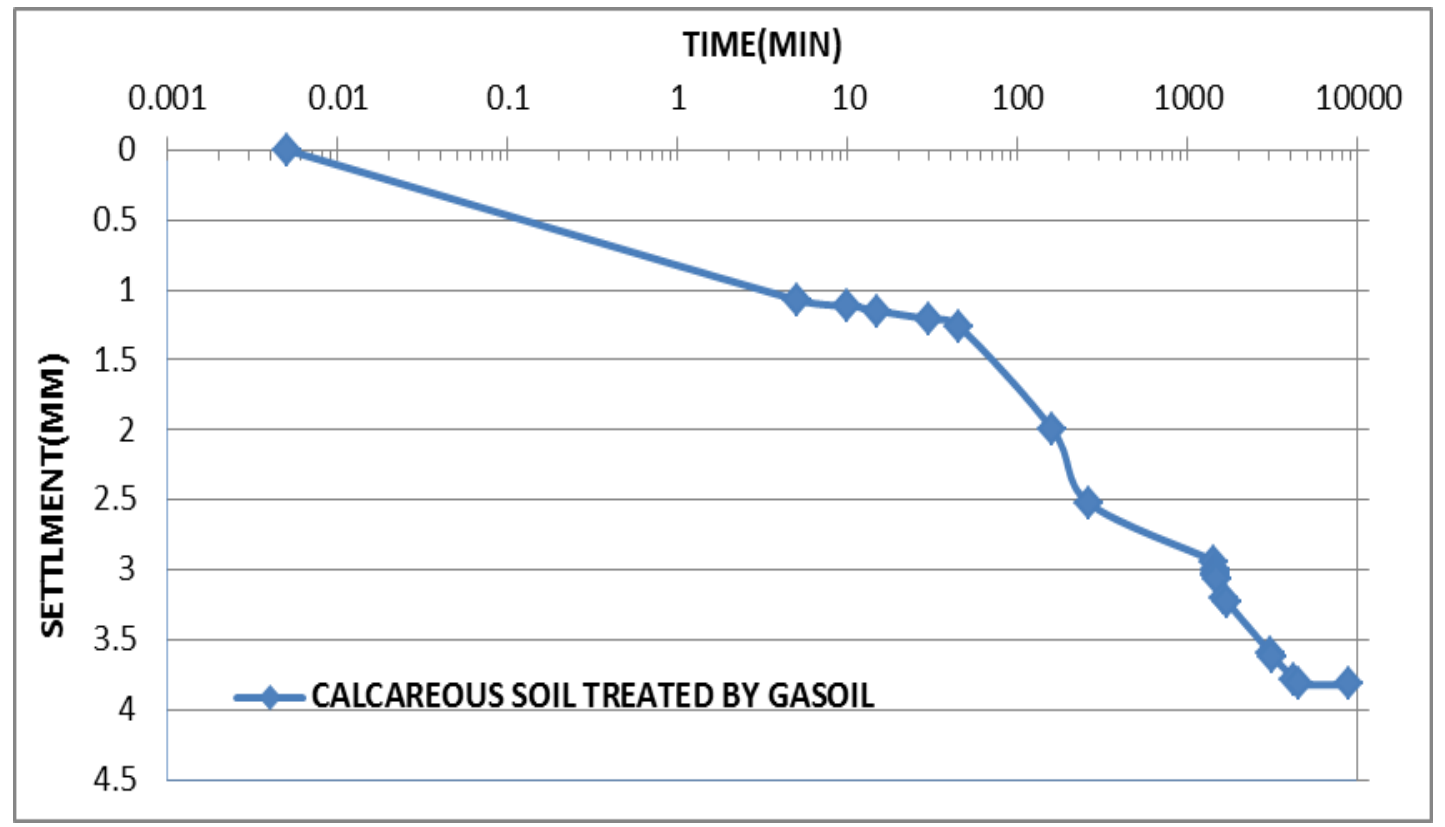

Fig. (8): Time-Settlement curve for Calcareous soil laboratory model with 70\% $\mathrm{CaCO}_{3}$ content, wetted by Gasoil. (soaking stress $=50 \mathrm{kPa}, \gamma \mathrm{d}=11 \mathrm{kN} / \mathrm{m}^{3}$ ).

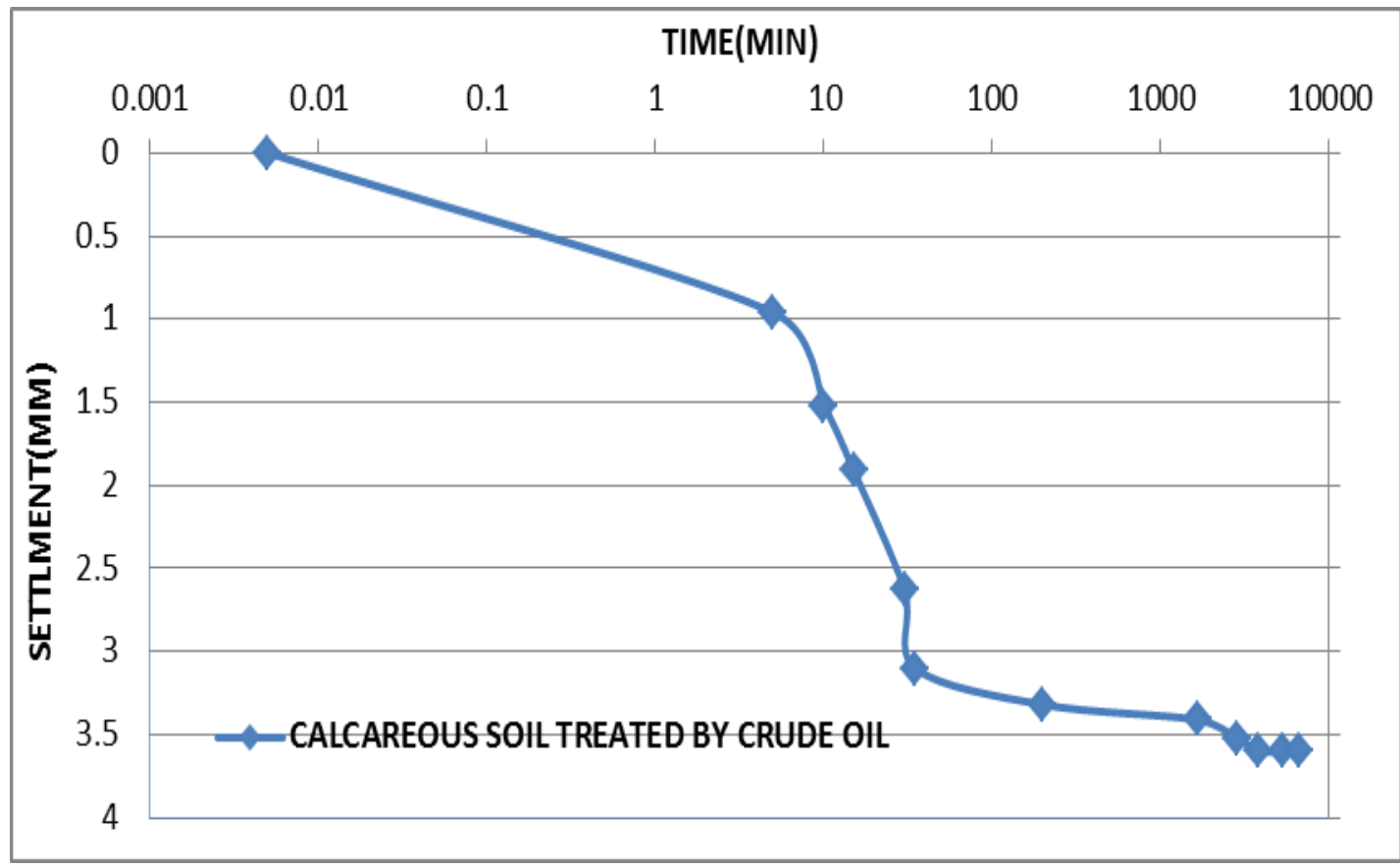

Fig. (9): Time-Settlement curve for Calcareous soil laboratory model with $70 \%$ $\mathrm{CaCO}_{3}$ content, lubricated with crude oil. (soaking stress $=50 \mathrm{kPa}, \gamma \mathrm{d}=11 \mathrm{kN} / \mathrm{m}^{3}$ ). 


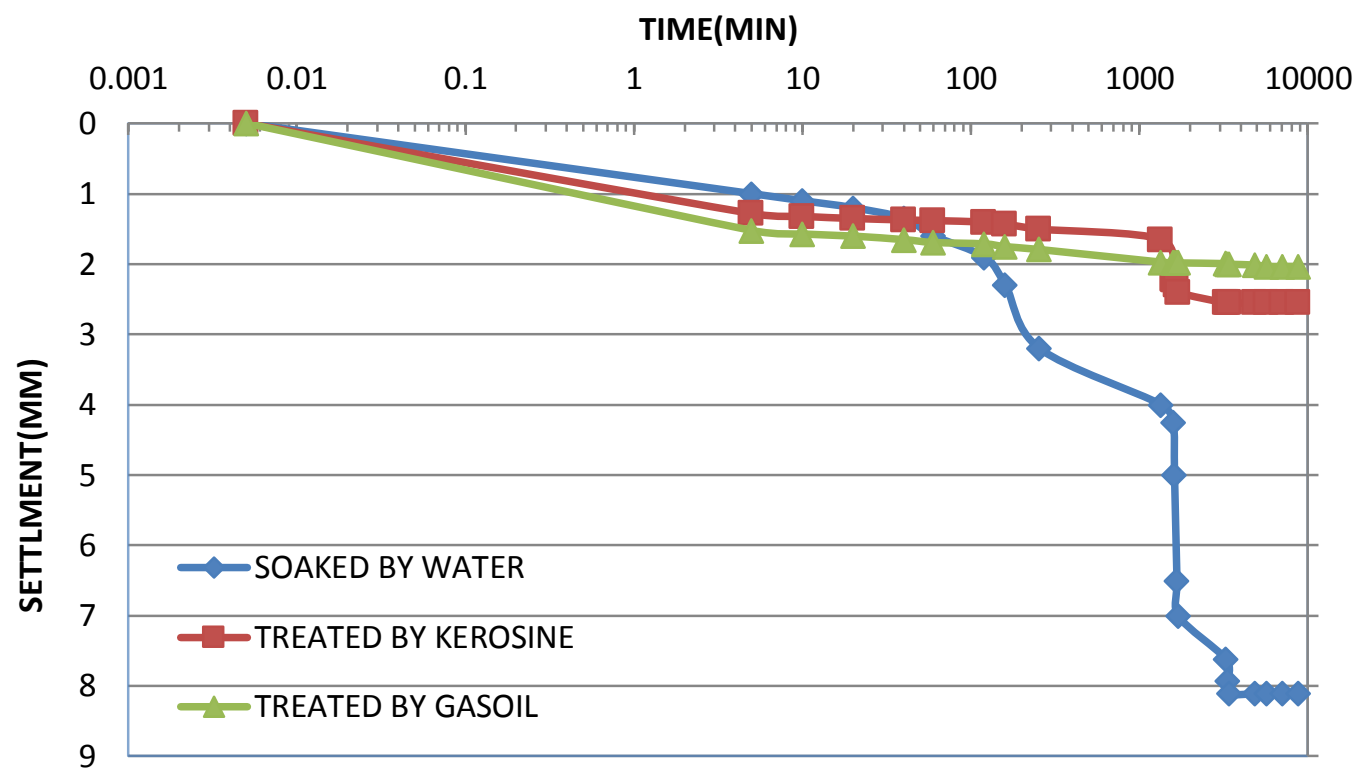

Fig. (10): Time-Settlement curve for Calcareous soil laboratory model with 50\%

$\mathrm{CaCO}_{3}$ content, wetted by oil derivatives(Kerosene and Gasoil), in addition to a model soaked by water. (soaking stress $=50 \mathrm{kPa}, \gamma \mathrm{d}=11 \mathrm{kN} / \mathrm{m}^{3}$ ).

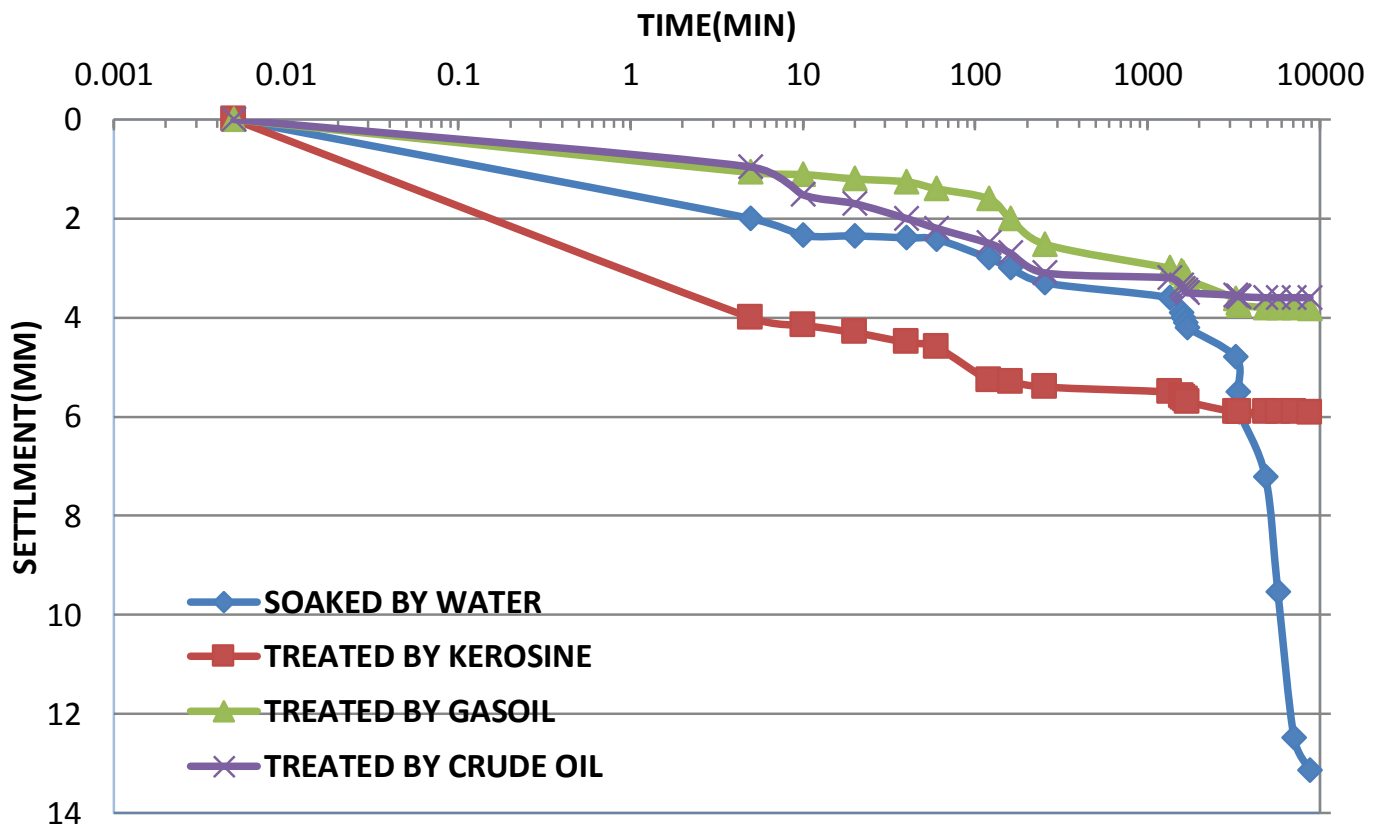

Fig. (11): Time-Settlement curve for Calcareous soil laboratory model with $70 \% \mathrm{CaCO}_{3}$ content, wetted by oil derivatives(Kerosene, Gasoil and Crude oil), in addition to a model soaked by water. (soaking stress $=50 \mathrm{kPa}, \gamma \mathrm{d}=11 \mathrm{kN} / \mathrm{m}^{3}$ ). 


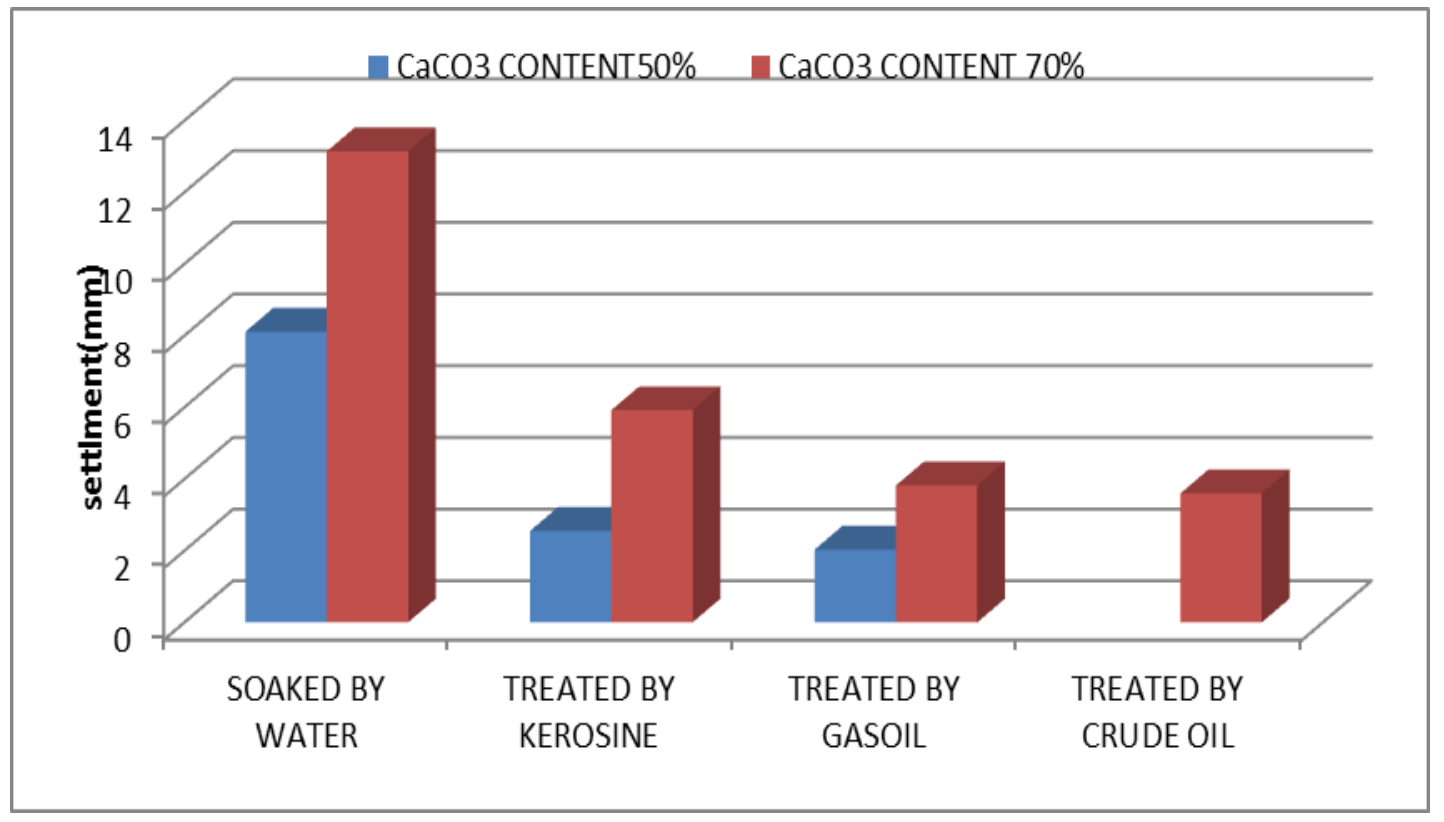

Fig. (12): A bar chart for Calcareous soil laboratory models containing 50\% and 70\% $\mathrm{CaCO}_{3}$ content, treated with different oil derivatives. (soaking stress $=50 \mathrm{kPa}, \gamma \mathrm{d}=11 \mathrm{kN} / \mathrm{m}^{3}$ ). 


\title{
تصرف التربة الكلسية المعرضة للمشتقات النفطية
}

\author{
صفاء حسين عبد عون 1، وعد عبد الستار حسين 2 \\ 1 مدرس، ${ }^{2}$
}

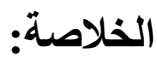

التربة الكلسية هي التربة التي تحتوي على املاح الصوديوم او الكالسيوم السريعة الذوبان بالماء في ظروف جوية

معينة. اذ تزداد سرعة الذوبان بزيادة درجة الحراره, الضغط الجوي اضافةً الى حامضية السائل المذيب. تمتاز هذه التربة بانها تكون قوية و متماسكة في حالة كونها في الحاله الجافه ولكن تظهر مشاكلها لحظة ترطيبها. حيث تشكل خطراً على المنشآت المقامه عليها خاصةً عند تعرض هذه المنشاَت لاحمال خارجيه. اذ ان اغمار هذه التربه بالماء يؤدي الى ذوبان الكلس وغسل للتربه نتيجةً لتفكك الروابط بين جزيئاتها وتكون فجوات فيها. في بعض مناطق وسط وشمال العراق تبلغ نسب الكلس اكثر من 50\% كما في محطة بيجي النفطيه و مدينة الموصل. خلال حدوث بعض التصدعات او الثقوق في انابيب نقل المنشاَت النفطيه لاى سبب، تتسرب المشتقات النفطيه الى التربه تحت اسسات المنشآت. يسلط هذا البحث الضوء حول امكانية دراسة تصرف التربه الكلسيه في حال تعرضها للاغمار ببعض المنتجات النفطيه, وتاثير هذه السوائل على انضغاطية التربه ذات المحتوى الكلسي العالي. تم استخدام موديل مختبري اسطواني الشكل، نوضع التربه الجبسيه التي نم تحضيرها مختبرياً بنسب كلس انس مختلفه:50\%،70\%. تم رص التربه بكثافة رص ثابته 11 (كيلو نيوتن/منز مكعب). تم تسليط اجهاد ثابت مقداره 50 كبلو نيوتن/منز مربع, بواسطة اوزان ثابته على اساس مستطيل. تم دراسة ناثير ترطيب التربه الكلسيه ببعض المشتقات النفطيه وهي (النفط الابيض، زيت الغاز ، زيت السيارات المستهلاك، اضافة الى نموذج يغمر بالماء لغرض المقارنه ودراسة علاقة الانهياريه مع الزمن عند اجهاد ثابت. اظهرت نتائج الفحوصات التي اجريت على الموديل المختبري ان الانهياريه للنماذج نتيجة الاغمار بالزيت المستهلك, النفط الابيض، زيت الغاز هو اقل بكثير من الانهياريه للنموذج المغمور بالماء (تقل الانهياريه الى التلث) والتي تعنبر تحسن كبير لهذه الترب الانهياريه, بواسطة تعريضها لهذه المشتقات النفطيه. كلمات الدالة: التربه الكلسيه، تصرف، انهير لهياريه، المشتقات النفطيه. 